\title{
PENGARUH PEMBIAYAAN SEKTOR EKONOMI PRIMER, SEKTOR EKONOMI SEKUNDER, DAN SEKTOR EKONOMI TERSIER TERHADAP NON PERFORMING FINANCING (NPF) PADA PERBANKAN SYARIAH DI INDONESIA PERIODE 2010-2015 (MARET) ${ }^{11}$
}

\author{
Imro Atul Mufidah \\ Program Studi S1 Ekonomi Islam-Fakultas Ekonomi dan Bisnis-Universitas Airlangga \\ Email : mufidahh223@yahoo.com \\ Fatin Fadhilah Hasib \\ Departemen Ekonomi Syariah-Fakultas Ekonomi dan Bisnis-Universitas Airlangga \\ Email : fatin.fadhilah@gmail.com
}

\begin{abstract}
:
The purpose of this study is to find out the influence of financing primary sector, secondary sector, and tertiary sector toward Non Performing Financing (NPF) of Islamic Banking In Indonesia. Quantitative approach applied in this study as a research method. Furthermore, a technique of data analysis used is multiple linier regression to analyse the impact of independent variable toward dependent variable. The independent variable are financing primary sector, secondary sector, and tertiary sector. Meanwhile, NPF is the dependent variable. The result of the study shows that financing partially in primary sector influenced NPF significantly. Whereas, partially secondary sector and tertiary sector did not influence significantly to NPF. The result of simultance test indicated that the growth of financing primary sector, secondary sector, and tertiary sector influenced significantly to NPF of islamic banking.
\end{abstract}

Keywords: Islamic Banking, NPF, Financing Economic Sector, Financing Primary Sector, Financing Secondary Sector, Financing Tertiary Sector.

\section{PENDAHULUAN}

Bank dalam menjalankan

aktivitasnya berfungsi sebagai lembaga intermediasi (financial intermediary), yaitu lembaga keuangan yang berfungsi sebagai perantara pihak yang kelebihan dana dengan pihak yang kekurangan dana. Harta memiliki fungsi ekonomis yang harus senantiasa diberdayakan agar aktifitas ekonomi berjalan sehat. Maka harta harus berputar dan bergerak di kalangan masyarakat, baik dalam bentuk konsumsi atau investasi (Dendawijaya, 2005:15). Sebagaimana dijelaskan secara tersirat pada Al-Qur'an Surat Al-Hasyr Ayat 7:

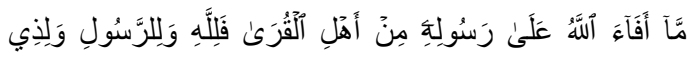

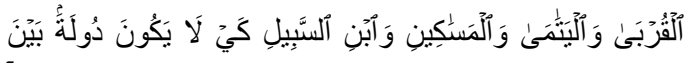

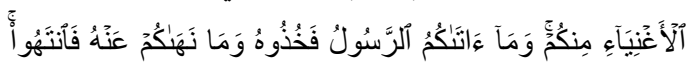

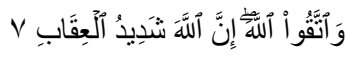

Apa saja harta rampasan (fa'il) yang diberikan Allah kepada rasul-Nya yang berasal dari penduduk kota-kota maka adalah untuk Allah, rasul, kerabat rasul, anak-anak yatim, orang-orang miskin dan orang-orang yang dalam perjalanan, supaya harta itu jangan hanya beredar diantara kamu. Apa yang diberikan rasul kepadamu maka terimalah dia. Dan apa yang dilarang bagimu maka tinggalkanlah, bertaqwalah kepada Allah. Sesungguhnya Allah sangat keras hukuman-Nya (Departemen Agama, 2010:1118).

\footnotetext{
1) Jurnal ini merupakan bagian dari skripsi dari Imro Atul Mufidah. NIM 041114133 , yang diuji pada 10
} Februari 2016 
Mufidah, et al/Jurnal Ekonomi Syariah Teori dan Terapan Vol. 3 No. 5 Mei 2016: 402-417; PENGARUH PEMBIAYAAN SEKTOR EKONOMI PRIMER, SEKTOR EKONOMI SEKUNDER, DAN SEKTOR EKONOMI TERSIER TERHADAP NON PERFORMING FINANCING (NPF) PADA PERBANKAN SYARIAH DI INDONESIA PERIODE 2010-2015 (MARET)

Maksud ayat diatas menjelaskan agar harta itu tidak hanya berputar pada lingkungan tertentu saja dari orang-orang kaya (kelebihan dana), tetapi tersebar pada berbagai pihak sehingga manfaatnya juga dirasakan oleh banyak pihak, dan harta (dana) dapat didistribusi secara merata.

Fungsi bank sebagai lembaga intermediary, juga menjadikan bank syariah ikut berperan aktif dalam mengembangkan dunia usaha, serta membantu memenuhi kebutuhan modal bagi usaha kecil, menengah, dan besar ataupun juga koperasi melalui produk pembiayaannya. Pembiayaan perbankan syariah harus tersedia untuk meningkatkan kesempatan kerja dan kesejahteraan ekonomi sesuai dengan nilai-nilai Islam. Pembiayaan yang disalurkan harus dapat dinikmati oleh para pengusaha yang bergerak di berbagai bidang untuk menunjang kesempatan kerja, menunjang produksi dan distribusi barang dan jasa dalam rangka untuk memenuhi kebutuhan masyarakat yang didasari oleh prinsip tolong menolong dalam kebaikan.

Pembiayaan pada bank syariah memiliki perbedaan prinsip dengan pembiayaan pada bank konvensional. Pembiayaan pada bank syariah, dana masyarakat yang digunakan tidak bersifat sebagai utang bank, tetapi dana titipan dan bank bertindak sebagai manajer dimana risiko investasinya ditanggung oleh para pemilik dana secara bersamaan. Pada bank konvensional, pembiayaan menggunakan sistem bunga atau riba.

Penyaluran pembiayaan bank syariah kepada masyarakat harus benarbenar selektif dalam menjalankan prinsip kehati-hatian. Hal ini dimaksudkan agar bank syariah dapat meminimalisir risiko yang akan dihadapi, misalnya pembiayaan bermasalah. Pembiayaan bermasalah atau yang dikenal dengan kredit macet terjadi apabila bank tidak bisa memperoleh kembali cicilan pokok dan atau bunga dari pembiayaan yang diberikan (Muhammad, 2002:310).

Pembiayaan bermasalah dalam dunia perbankan syariah dikenal dengan Non Performing Financing (NPF). NPF merupakan rasio perbandingan antara jumlah pembiayaan yang dinilai bermasalah dengan jumlah pembiayaan yang telah disalurkan bank syariah. Semakin tinggi NPF, maka semakin tidak sehat bank tersebut.

Pembiayaan sektor ekonomi juga tidak lepas dari terjadinya risiko. Pada Tabel 1 memperlihatkan bahwa pembiayaan non lancar pada pembiayaan sektor ekonomi meningkat seiring dengan meningkatnya pembiayaan pada sektor ekonomi. Selain itu, dapat disimpulkan bahwa meningkatnya pembiayaan berpengaruh positif terhadap pembiayaan non lancar 
Mufidah, et al/Jurnal Ekonomi Syariah Teori dan Terapan Vol. 3 No. 5 Mei 2016: 402-417; PENGARUH PEMBIAYAAN SEKTOR EKONOMI PRIMER, SEKTOR EKONOMI SEKUNDER, DAN SEKTOR EKONOMI TERSIER TERHADAP NON PERFORMING FINANCING (NPF) PADA PERBANKAN SYARIAH DI INDONESIA PERIODE 2010-2015 (MARET)

yang berimbas pada tingkat NPF perbankan syariah. Hal ini diperkuat pada penelitian terdahulu yang dilakukan oleh Mohammad Nasih (2013) yang menyimpulkan bahwa naiknya tingkat pembiayaan berpengaruh terhadap pertumbuhan NPF.

Tabel 1.

Pembiayaan Non Lancar Bank Umum Syariah Berdasarkan Pembiayaan Sektor Ekonomi Tahun 2010 - Maret 2015 (dalam satuan milyar)

\begin{tabular}{|l|r|r|r|}
\hline \multicolumn{1}{|c|}{ Sektor Ekonomi } & $\mathbf{2 0 1 3}$ & $\mathbf{2 0 1 4}$ & $\begin{array}{c}\mathbf{2 0 1 5} \\
\text { (Maret) }\end{array}$ \\
\hline $\begin{array}{l}\text { 1. Pertanian, } \\
\text { Kehutanan } \\
\text { \& Sarana Pertanian }\end{array}$ & 166 & 404 & 471 \\
\hline 2. Pertambangan & 21 & 439 & 496 \\
\hline 3. Perindustrian & 256 & 524 & 630 \\
\hline 4. Listrik, Gas dan Air & 10 & 395 & 395 \\
\hline 5. Konstruksi & 405 & 854 & 878 \\
\hline $\begin{array}{l}\text { 6. Perdagangan, } \\
\text { Restoran dan Hotel }\end{array}$ & 604 & 1.536 & 1.592 \\
\hline $\begin{array}{l}\text { 7. Pengangkutan, } \\
\text { Pergudangan \& } \\
\text { Komunikasi }\end{array}$ & 314 & 837 & 1.102 \\
\hline 8. Jasa Dunia Usaha & 1.286 & 1.899 & 2.010 \\
\hline $\begin{array}{l}\text { 9. Jasa Sosial / } \\
\text { Masyarakat }\end{array}$ & 205 & 585 & 718 \\
\hline 10. Lain-lain & 1.559 & 1.159 & 1.358 \\
\hline Total & 4.828 & 8.632 & 9.650 \\
\hline
\end{tabular}

Sumber: OJK, Statistik Perbankan Syariah (SPS), Maret 2015

Pembiayaan sektor ekonomi yang terus meningkat setiap tahunnya memberi pengaruh terhadap pertumbuhan NPF, dan diperkuat oleh penelitian yang dilakukan $M$. Hasan Basori (2009) bahwa pertumbuhan seluruh pembiayaan sektor ekonomi secara simultan berpengaruh terhadap pertumbuhan NPF. Secara parsial, pertumbuhan pembiayaan yang berpengaruh terhadap NPF hanya sektor ekonomi primer dan tersier, sedangkan pada sektor ekonomi sekunder tidak. Sedangkan penelitian lainnya yang dilakukan oleh Taufiqurrahman (2008), menghasilkan kesimpulan seluruh sektor ekonomi secara simultan berpengaruh secara signifikan terhadap NPF. Secara parsial, hanya sektor sekunder yang berpengaruh terhadap NPF.

Kedua penelitian tersebut memiliki hasil penelitian yang berbeda, terutama pada pengaruh secara parsial antara variabel independen dalam memengaruhi variabel dependen, sehingga perlu dilakukan penelitian lebih lanjut untuk membuktikan pengaruh secara parsial dan simultan pembiayaan sektor ekonomi terhadap NPF pada bank umum syariah periode Januari 2012 sampai Maret 2015.

Berdasarkan uraian yang telah dijelaskan, maka peneliti dapat merumuskan masalah penelitian sebagai berikut:

1. Apakah pembiayaan pada ketiga sektor ekonomi (sektor ekonomi primer, sektor ekonomi sekunder, dan sektor ekonomi tersier) secara simultan berpengaruh terhadap tingkat pembiayaan bermasalah (NPF) pada Bank Umum Syariah di Indonesia periode 2012-2015?

2. Apakah pembiayaan pada ketiga sektor ekonomi (sektor ekonomi 
Mufidah, et al/Jurnal Ekonomi Syariah Teori dan Terapan Vol. 3 No. 5 Mei 2016: 402-417; PENGARUH PEMBIAYAAN SEKTOR EKONOMI PRIMER, SEKTOR EKONOMI SEKUNDER, DAN SEKTOR EKONOMI TERSIER TERHADAP NON PERFORMING FINANCING (NPF) PADA PERBANKAN SYARIAH DI INDONESIA PERIODE 2010-2015 (MARET)

primer, sektor ekonomi sekunder, dan sektor ekonomi tersier) secara parsial berpengaruh terhadap tingkat pembiayaan bermasalah (NPF) pada Bank Umum Syariah di Indonesia periode 2012-2015?

Adapun tujuan penelitian ini adalah Untuk mengetahui pembiayaan pada tiga sektor ekonomi secara simultan dan parsial berpengaruh terhadap tingkat pembiayaan bermasalah (NPF) Bank Umum Syariah di Indonesia periode 2012-2015.

\section{LANDASAN TEORI DAN PEMBAHASAN HIPOTESIS}

Aktifitas bisnis pada perbankan akan selalu berhadapan dengan risiko. Jenis resiko yang berhubungan dengan bisnis perbankan diantaranya adalah risiko likuiditas (liquidity risk), risiko tingkat bunga (interest rate risk), risiko nilai tukar valuta asing (foreign exchange rate risk), risiko operasional (operational risk), dan risiko kredit (credit risk) (Muhammad, 2002:309).

Risiko kredit juga merupakan risiko besar yang dihadapi perbankan, termasuk pula perbankan syariah. Menurut Muhammad (2002:310), risiko kredit muncul apabila bank tidak memperoleh cicilan pokok dan atau bunga dari pinjaman yang diberikannya atau investasi yang sedang dilakukannya. Penyebab utama terjadinya risiko kredit adalah terlalu mudahnya bank memberikan pinjaman atau melakukan investasi karena terlalu dituntut untuk memanfaatkan kelebihan likuiditas, sehingga kurang cermat dalam mengantisipasi berbagai kemungkinan risiko usaha yang dibiayai.

Risiko kredit macet dalam dunia perbankan dikenal dengan non performing loans (NPL) atau pada bank syariah lebih dikenal dengan non performing financing (NPF). Besar angka NPL maupun NPF dihitung dari perbandingan antara kredit macet atau bermasalah dengan total pemberian kredit perbankan (Anshori, 2007:4).

Risiko kredit macet dapat dijumpai pada semua jenis pembiayaan yang disalurkan bank syariah, termasuk pula pada pembiayaan berdasarkan sektor ekonomi, ditunjukkan pada grafik 2.1 sebagai berikut.

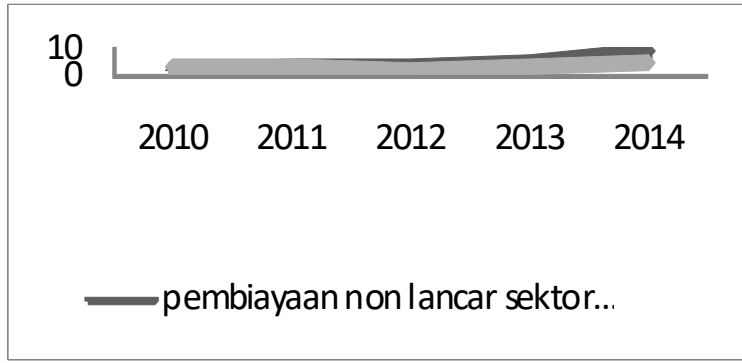

Sumber: OJK, Statistik Perbankan Indonesia (SPI), Maret 2015

Gambar 1.

Pertumbuhan Pembiayaan Non Lancar Sektor Ekonomi dan NPF Periode 2010 - Maret 2015

Kredit macet atau pembiayaan non lancar pada sektor ekonomi disetiap tahunnya terus meningkat, dan puncak tertinggi periode Januari 2010 sampai Maret 2014 terjadi pada Maret 2015 sebesar 9.654 
Mufidah, et al/Jurnal Ekonomi Syariah Teori dan Terapan Vol. 3 No. 5 Mei 2016: 402-417; PENGARUH PEMBIAYAAN SEKTOR EKONOMI PRIMER, SEKTOR EKONOMI SEKUNDER, DAN SEKTOR EKONOMI TERSIER TERHADAP NON PERFORMING FINANCING (NPF) PADA PERBANKAN SYARIAH DI INDONESIA PERIODE 2010-2015 (MARET)

milyar rupiah. Besar pembiayaan non lancar juga turut mempengaruhi semakin meningkatnya total NPF, walaupun tinggi nilai NPF sampai pada Maret masih dibawah $5 \%$, yaitu sebesar $4,81 \%$.

\section{METODE PENELITIAN}

Pendekatan penelitian yang digunakan dalam penelitian ini merupakan pendekatan kuantitatif. Penelitian ini menitik beratkan pada pendekatan secara empiris dengan menggunakan statistik inferensial parametik. Statistik inferensial parametik artinya setelah data dikumpulkan, maka dilakukan berbagai metode statistik untuk menganalisa data dan kemudian menginterpretasikan hasil analisa tersebut dengan memakai skala rasio. Skala rasio merupakan skala dimana angka mempunyai makna yang sesungguhnya (Santoso, 2000:4). Dalam skala rasio, angka nol (0) ini diperlukan sebagai dasar perhitungan dan pengukuran objek penelitian (Sujoko, 2004:18).

Dalam penelitian ini variabelvariabel yang digunakan sebagai berikut:

1. Variabel bebas (variabel independen) yang dibagi menjadi tiga variabel, yaitu: Pembiayaan Sektor Ekonomi Primer $\left(X_{1}\right)$, Pembiayaan Sektor Ekonomi Sekunder $\left(\mathrm{x}_{2}\right)$, Pembiayaan Sektor Tersier $\left(X_{\Omega}\right)$.
2. Variabel terikat (variabel dependen) yaitu: Non Performing Financing pada Bank Umum Syariah (Y)

\section{DEFINISI OPERASIONAL}

1. Non Performing Financing (NPF)

Pembiayaan bermasalah atau Non Performing Financing (NPF) menunjukkan kemampuan manajemen bank dalam mengelola pembiayaan bermasalah yang diberikan bank. Variabel NPF merupakan variabel dependen dalam penelitian ini. Data NPF bersumber dari Statistik Perbankan Syariah (Rasio Keuangan pada Bank Umum Syariah) periode Januari 2010-Maret 2015 yang berjumlah 39 data. NPF diperoleh dengan cara membandingkan antara pembiayaan non lancar $(K L, D, M)$ dengan total pembiayaan.

\section{Pembiayaan Sektor Ekonomi Primer}

Sektor ekonomi ini terdiri dari dua sektor, yaitu sektor ekonomi pertanian, kehutanan, sarana pertanian dan sektor pertambangan. Variabel pembiayaan sektor ekonomi primer merupakan variabel independen dalam penelitian ini. Data pembiayaan sektor ekonomi primer bersumber dari Statistik Perbankan Syariah (Rasio Keuangan pada Bank Umum Syariah) periode Januari 2010-Maret 2015 yang berjumlah 63 data.

3. Pembiayaan Sektor Ekonomi Sekunder Sektor ekonomi ini terdiri atas tiga sektor, yaitu industri; sektor listrik, air dan gas; serta sektor konstruksi. Variabel 
Mufidah, et al/Jurnal Ekonomi Syariah Teori dan Terapan Vol. 3 No. 5 Mei 2016: 402-417; PENGARUH PEMBIAYAAN SEKTOR EKONOMI PRIMER, SEKTOR EKONOMI SEKUNDER, DAN SEKTOR EKONOMI TERSIER TERHADAP NON PERFORMING FINANCING (NPF) PADA PERBANKAN SYARIAH DI INDONESIA PERIODE 2010-2015 (MARET)

pembiayaan sektor ekonomi sekunder merupakan variabel independen dalam penelitian ini. Data pembiayaan sektor ekonomi sekunder bersumber dari Statistik Perbankan Syariah (Rasio Keuangan pada Bank Umum Syariah) periode Januari 2010Maret 2015 yang berjumlah 63 data.

\section{Pembiayaan Sektor Tersier}

Sektor ekonomi tersier ini terdiri atas lima sektor, yang meliputi sektor perdagangan, restoran, dan hotel; sektor pengangkutan, pergudangan, komunikasi; sektor jasa dunia usaha; sektor jasa sosial; dan sektor lain-lain. Variabel pembiayaan sektor ekonomi tersier merupakan variabel independen dalam penelitian ini. Data pembiayaan sektor ekonomi tersier bersumber dari Statistik Perbankan Syariah (Rasio Keuangan pada Bank Umum Syariah) periode Januari 2010-Maret 2015 yang berjumlah 63 data.

\section{Jenis dan Sumber Data}

Dalam melaksanakan penelitian ini, data yang dipergunakan adalah data sekunder yang berupa rasio keuangan pada Bank Umum Syariah. Data yang dipergunakan dalam penelitian ini merupakan data sekunder yang diperoleh dari Statistik Perbankan Syariah (SPS). Data tersebut diterbitkan dalam website resmi Bank Indonesia dan website resmi Otoritas Jasa Keuangan (OJK). Periode data menggunakan Statistik Perbankan Syariah
(Rasio Keuangan pada Bank Umum Syariah) periode Januari 2010-Maret 2015.

\section{Prosedur Pengumpulan Data}

Prosedur pengumpulan data dilakukan melalui studi pustaka dengan mengkaji buku-buku literatur, jurnal, makalah, dan sumber-sumber lainnya yang berkaitan dengan penelitian. $\mathrm{Hal}$ itu, dengan tujuan untuk memperoleh landasan teoritis secara komprehensif (mudah diterima atau dipahami) terkait industri perbankan syariah.

\section{Teknik Analisis}

Teknik analisis yang digunakan dalam penelitian ini adalah regresi linier berganda dengan time series. Teknik analisis ini juga digunakan untuk memperoleh informasi dalam mengetahui pengaruh, ada atau tidaknya pengaruh pembiayaan sektor ekonomi primer, sekunder, tersier terhadap NPF pada bank umum syariah. Adapun alat analisis yang digunakan adalah analisis regresi linier berganda, dengan melakukan uji linieritas terlebih dahulu kemudian melakukan uji asumsi klasik. 
Mufidah, et al/Jurnal Ekonomi Syariah Teori dan Terapan Vol. 3 No. 5 Mei 2016: 402-417; PENGARUH PEMBIAYAAN SEKTOR EKONOMI PRIMER, SEKTOR EKONOMI SEKUNDER, DAN SEKTOR EKONOMI TERSIER TERHADAP NON PERFORMING FINANCING (NPF) PADA PERBANKAN SYARIAH DI INDONESIA PERIODE 2010-2015 (MARET)

\section{HASIL DAN PEMBAHASAN}

Tabel 2.

Uji Linieritas dengan Remsey Test

\begin{tabular}{|c|c|r|r|r|}
\multicolumn{9}{c|}{ Model Summarry } \\
\hline$R$ & $\begin{array}{c}R \\
\text { Square }\end{array}$ & $\begin{array}{c}\text { Adj. } \\
R \\
\text { Square }\end{array}$ & $\begin{array}{c}\text { Std. Error } \\
\text { Of the } \\
\text { Estimate }\end{array}$ & $\begin{array}{l}\text { Durbin- } \\
\text { Watson }\end{array}$ \\
\hline $.484 a$ & .235 & .196 & .09181 & 2.222 \\
\hline
\end{tabular}

Sumber: hasil olahan SPSS Statistic version 20

a. Predictors: (Constant), Pembiayaan Sektor Tersier, Pembiayaan Sektor Sekunder,

Pembiayaan Sektor Primer

b. Dependent Variable: LN NPF

Old Regression

Tabel 3.

Uji Linieritas dengan Remsey Test

New Regression

Model Summary

\begin{tabular}{|c|c|c|c|}
\hline$R$ & $\begin{array}{c}R \\
\text { Square }\end{array}$ & $\begin{array}{c}\text { Adjusted } \\
R \text { Square }\end{array}$ & $\begin{array}{c}\text { Std. Error of } \\
\text { the Estimate }\end{array}$ \\
\hline $.927 a$ & .759 & .850 & .06783705 \\
\hline
\end{tabular}

Sumber: hasil olahan SPSS Statistic version 20

a. Predictors: (Constant), Pembiayaan Sektor Tersier, Pembiayaan Sektor Sekunder, DFFIT, Pembiayaan Sektor Primer

Dari tabel tersebut dapat diketahui hasil regresi DFitt dihasilkan nilai $R$ Square $(R$ Square New) sebesar 0,759 dan hasil regresi awal dihasilkan nilai R Square (R Square Old) sebesar 0,235.

Ramsey Test dihitung dengan rumus:

F hitung $=\frac{\left(\mathbb{R}_{\mathrm{new}}^{2}-\mathbb{R}_{\text {ola }}^{2}\right) / \mathrm{m}}{\left(1-\mathbb{R}_{\mathrm{new}}^{2}\right) /(\mathrm{n}-\mathrm{k})}$

Keterangan:

$\mathrm{m}$ : banyak variabel bebas yang dimasukkan (3 variabel bebas + DFitt $=4$ ) k: banyak parameter dalam persamaan baru (NPF + 3 variabel bebas + Dfitt $=5)$

$\mathrm{n}$ : banyak sampel penelitian (63)

Dari angka di atas dihitung nilai $F$ untuk Ramsey Test sebagai berikut:

$F=\frac{0.0759-0255 / 4}{(1-0795) /(63-5)}$

$F=39,61$

$\mathrm{F}$ Tabel adalah $\mathrm{F}$ table dengan df $1=\mathrm{k}(4)$; $\mathrm{df2}=\mathrm{n}-\mathrm{k}-1 \quad(57)$

F hitung Ramsey 31,61 > F table 2,534 maka dapat disimpulkan bahwa asumsi linieritas regresi sudah dapat dipenuhi.

Tabel 4

Uji Normalitas dengan KolmogrovSmirnov test One-Sample Kolmogrov Smirnov Test

\begin{tabular}{|ll|r|}
\hline & & $\begin{array}{c}\text { Unstandardized } \\
\text { Residual }\end{array}$ \\
\hline $\mathrm{N}$ & Mean & 63 \\
Normal & .0000000000000 \\
Parametersa,b & Std. & 5 \\
& Deviation & .08955823 \\
Most Extreme & Absolute & .133 \\
Differences & Positive & .133 \\
Kolmogorov-Smirnov Z & -.119 \\
Asymp. Sig. (2-tailed) & 1.056 \\
\hline
\end{tabular}

Sumber: hasil olahan SPSS Statistic version 20

a. Test distribution is Normal.

b. Calculated from data.

Berdasarkan hasil pengujian di atas, diketahui bahwa nilai signifikansi dari statistik uji Kolmogrov-Smirnov adalah sebesar 0,214. Nilai tersebut lebih besar dari $a=0,05$, sehingga dapat dapat disimpulkan bahwa data yang diuji berdistribusi normal. 
Mufidah, et al/Jurnal Ekonomi Syariah Teori dan Terapan Vol. 3 No. 5 Mei 2016: 402-417; PENGARUH PEMBIAYAAN SEKTOR EKONOMI PRIMER, SEKTOR EKONOMI SEKUNDER, DAN SEKTOR EKONOMI TERSIER TERHADAP NON PERFORMING FINANCING (NPF) PADA PERBANKAN SYARIAH DI INDONESIA PERIODE 2010-2015 (MARET)

Tabel 5.

Uji Multikolinearitas

coefficients ${ }^{a}$

\begin{tabular}{|c|r|c|}
\hline \multirow{2}{*}{ Model } & \multicolumn{2}{|c|}{ Collinearity Statistics } \\
\cline { 2 - 3 } & Tolerance & \multicolumn{1}{c|}{ VIF } \\
\hline \multicolumn{1}{|c|}{ (Constant) } \\
$\begin{array}{l}\text { Pembiayaan } \\
\text { Sektor Primer }\end{array}$ & .762 & 1.312 \\
$1 \quad \begin{array}{l}\text { Pembiayaan } \\
\text { Sektor Sekunder } \\
\text { Pembiayaan } \\
\text { Sektor Tersier }\end{array}$ & .780 & 1.282 \\
\hline
\end{tabular}

Sumber: hasil olahan SPSS Statistic version 20

a. Dependent Variable : NPF

Dari tabel uji multikolinearitas di atas, dapat dilihat nilai VIF sektor primer 1,312 dan tolerance value sebesar 0,762 , nilai VIF sektor sekunder 1,282 dan tolerance value 0,780, nilai VIF sektor tersier 1,027 dan tolerance value 0,974, Sehingga dapat disimpulkan bahwa antara sektor primer, sektor sekunder, dan sektor tersier tidak terdapat multikolinearitas karena nilai $\mathrm{VIF}<10$, dan tolerance value $>0,1$.

Nilai dL dan dU dapat dilihat pada tabel Durbin Waston, yaitu nilai $\mathrm{dL}$; $\mathrm{dU} ; \mathrm{a} ; \mathrm{n}$ ; $(k-1)$. Keterangan: $n$ adalah jumlah sampel, k adalah jumlah variabel, dan a adalah taraf signifikan. Dari tabel Durbin Waston didapat $\mathrm{dL}=1,4943$ dan $\mathrm{DU}=$ 1,6932. Dari tabel model summary didapatkan nilai Durbin Watson sebesar 2,222 dan nilai tersebut berada dalam rentang $\mathrm{dU}<\mathrm{d}<4-\mathrm{dU}$ yaitu $1,6932<2,222$ $<2,3068$ sehingga dapat diputuskan untuk menerima $H_{0}$, dan dapat disimpulkan bahwa tidak terdapat autokorelasi, atau dapat dikatakan bahwa asumsi nonautokorelasi terpenuhi.

Tabel 6.

Uji Autokorelasi dengan Durbin Watson Model Summaryb

\begin{tabular}{|c|l|l|l|l|}
\hline $\mathbf{R}$ & $\mathbf{R}$ Square & $\begin{array}{c}\text { Adj } \mathbf{R} \\
\text { Square }\end{array}$ & $\begin{array}{c}\text { Std. Error } \\
\text { of the } \\
\text { Estimate }\end{array}$ & $\begin{array}{c}\text { Durbin } \\
\text { Watson }\end{array}$ \\
\hline $.484 \mathrm{a}$ & .235 & .196 & .09181 & 2.222 \\
\hline
\end{tabular}

Sumber: hasil olahan SPSS Statistic version 20

a. Predictors: (Constant), Pembiayaan Sektor Primer, Pembiayaan Sektor Sekunder, Pembiayaan Sektor Tersier

b. Dependent Variabel: LN NPF

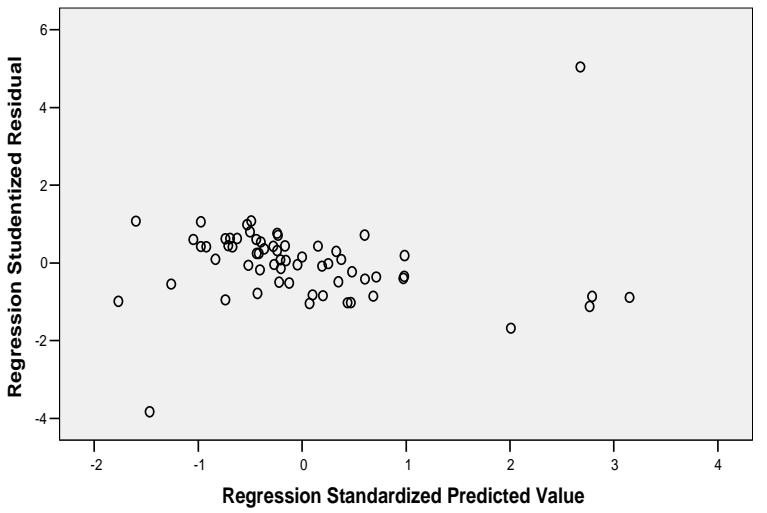

Gambar 2. Output Grafik Scatterrplot

Output grafik Scatterplot menunjukkan bahwa titik-titik menyebar di atas dan di bawah atau di sekitar 0, titik-titik data tidak mengumpul hanya di atas atau di bawah saja. Hal ini juga diperkuat dengan uji glejser yang menunjukkan bahwa nilai signifikansi t regresi glejser untuk semua variabel bebas sudah lebih besar dari 0,05 . Maka dapat disimpulkan tidak terjadi heteroskedastisitas. 
Mufidah, et al/Jurnal Ekonomi Syariah Teori dan Terapan Vol. 3 No. 5 Mei 2016: 402-417; PENGARUH PEMBIAYAAN SEKTOR EKONOMI PRIMER, SEKTOR EKONOMI SEKUNDER, DAN SEKTOR EKONOMI TERSIER TERHADAP NON PERFORMING FINANCING (NPF) PADA PERBANKAN SYARIAH DI INDONESIA PERIODE 2010-2015 (MARET)

Tabel 7.

Uji Heteroskedatisitas

Coefficientsa

\begin{tabular}{|c|c|c|c|c|c|}
\hline & \multicolumn{2}{|c|}{$\begin{array}{l}\text { Unstan- } \\
\text { dardized } \\
\text { Coefficients }\end{array}$} & \multirow{2}{*}{\begin{tabular}{|c}
$\begin{array}{c}\text { Stand- } \\
\text { ardized } \\
\text { Coefficie } \\
\text { nts }\end{array}$ \\
Beta
\end{tabular}} & \multirow[t]{2}{*}{$\mathrm{T}$} & \multirow[t]{2}{*}{ Sig. } \\
\hline & B & $\begin{array}{l}\text { Std. } \\
\text { Error }\end{array}$ & & & \\
\hline \multirow{8}{*}{$\begin{array}{l}\text { (Consan } \\
\text { t) } \\
\text { Pembia } \\
\text { yaan } \\
\text { Sektor } \\
\text { Primer } \\
\text { Pembia } \\
\text { yaan } \\
\text { Sektor } \\
\text { Sekund } \\
\text { er } \\
\text { Pembia } \\
\text { yaan } \\
\text { Sektor } \\
\text { Tersier }\end{array}$} & .048 & .015 & & 3.263 & .002 \\
\hline & & & & & \\
\hline & .212 & .195 & .158 & 1.086 & .282 \\
\hline & & & & & \\
\hline & .175 & .240 & .105 & .729 & .469 \\
\hline & & & & & \\
\hline & & & & & \\
\hline & .008 & .423 & .003 & .020 & .984 \\
\hline
\end{tabular}

Sumber: hasil olahan SPSS Statistic version 20

a. Dependent Variable: Absolut Residual

Tabel 8.

Koefisien Korelasi dan Koefisien Determinasi Multipel

Model Summary ${ }^{b}$

\begin{tabular}{|c|c|c|c|c|}
\hline$R$ & $\begin{array}{c}R \\
\text { Square }\end{array}$ & $\begin{array}{c}\text { Adjusted } \\
R \\
\text { Square }\end{array}$ & $\begin{array}{c}\text { Std.Error } \\
\text { of the } \\
\text { Estimate }\end{array}$ & $\begin{array}{c}\text { Durbin } \\
\text { Watson }\end{array}$ \\
\hline $.484 \mathrm{a}$ & .235 & .196 & .09181 & 2.222 \\
\hline
\end{tabular}

Sumber: hasil olahan SPSS Statistic version 20

a. Predictors: (Constant), Pembiayaan Sektor

Primer, Pembiayaan Sektor Sekunder,

Pembiayaan Sektor Tersier

b. Dependent Variabel: LN NPF

Koefisien determinasi $\left(R^{2}\right)$ sebesar

0,235 memberi pengertian bahwa variabel independen yg diteliti memiliki pengaruh kontribusi sebesar 23,5\% terhadap variabel NPF, sedangkan $76,5 \%$ lainnya dipengaruhi oleh faktor-faktor lain diluar variabel yg diteliti.

Tabel 9. Analisis Regresi Linier Berganda

\begin{tabular}{|c|c|l|}
\hline Variabel & $\begin{array}{c}\text { Unstandardized } \\
\text { Coefficients }(\beta)\end{array}$ & Keterangan \\
\hline Konstanta & 0,410 & $\begin{array}{c}\text { Merupakan } \\
\text { Intersep }\end{array}$ \\
\hline $\begin{array}{c}\text { Sektor } \\
\text { Primer }\end{array}$ & 0,885 & Bernilai positif \\
\hline $\begin{array}{c}\text { Sektor } \\
\text { Sekunder }\end{array}$ & 0,002 & Bernilai positif \\
\hline Sektor Tersier & $-0,799$ & $\begin{array}{c}\text { Bernilai } \\
\text { negative }\end{array}$ \\
\hline
\end{tabular}

Sumber: hasil olahan SPSS Statistic version 20

Berdasarkan nilai $\beta$ pada tabel di atas, maka persamaan untuk regresi linier berganda dalam penelitian ini dapat ditulis sebagai berikut:

$\mathrm{NPF}=0,410+0,885 \mathrm{X}_{1}+0,002 \mathrm{X}_{2}+-0,799 \mathrm{X}_{3}$

Interpretasi model persamaan:

1. Mengasumsikan bahwa pengaruh sektor sekunder dan sektor tersier konstan, maka kenaikan 1 unit sektor primer dan sektor tersier akan menyebabkan kenaikan 0,885 unit NPF. Nilai positif pada sektor primer menunjukkan hubungan searah antara variabel sektor primer dengan NPF.

2. Mengasumsikan bahwa pengaruh sektor primer dan sektor tersier konstan, maka kenaikan 1 unit sektor sekunder akan menyebabkan kenaikan 0,002 unit NPF. Nilai positif pada sektor sekunder menunjukkan hubungan searah antara variabel sektor sekunder dengan NPF.

3. Mengasumsikan bahwa pengaruh sektor primer dan sektor sekunder 
Mufidah, et al/Jurnal Ekonomi Syariah Teori dan Terapan Vol. 3 No. 5 Mei 2016: 402-417; PENGARUH PEMBIAYAAN SEKTOR EKONOMI PRIMER, SEKTOR EKONOMI SEKUNDER, DAN SEKTOR EKONOMI TERSIER TERHADAP NON PERFORMING FINANCING (NPF) PADA PERBANKAN SYARIAH DI INDONESIA PERIODE 2010-2015 (MARET)

konstan, maka kenaikan 1 unit sektor tersier akan menyebabkan penurunan 0,799 unit NPF. Nilai negatif pada sektor tersier menunjukkan hubungan tidak searah antara variabel sektor tersier dengan NPF.

\section{Pengujian Hipotesis}

Tabel 10.

Hasil Uji F

ANOVA ${ }^{b}$

\begin{tabular}{|l|r|r|r|c|c|}
\hline & $\begin{array}{c}\text { Sum of } \\
\text { Squares }\end{array}$ & df & $\begin{array}{c}\text { Mean } \\
\text { Square }\end{array}$ & $\mathrm{F}$ & Sig. \\
\hline Regression & .153 & 3 & .051 & 6.032 & $.001 \mathrm{a}$ \\
Residual & .497 & 59 & .008 & & \\
Total & .650 & 62 & & & \\
\hline
\end{tabular}

Sumber: hasil olahan SPSS Statistic version 20 a. Predictors: (Constant), Pembiayaan Sektor Primer, Pembiayaan Sektor Sekunder, Pembiayaan Sektor Tersier

b. Dependent Variabel: LN NPF

Berdasarkan hasil uji secara simultan di atas, didapatkan sig adalah $<0,05$ yaitu sebesar 0,001 maka $\mathrm{H}_{0}$ ditolak dan dapat disimpulkan bahwa secara bersama-sama (simultan) sektor primer, sektor sekunder dan sektor tersier berpengaruh signifikan terhadap NPF.

Berdasarkan hasil uji secara parsial, dapat diketahui bahwa peubah pembiayaan sektor primer memiliki sig $<0,05$ yaitu sebesar 0,002 maka $\mathrm{H}_{0}$ ditolak, dan dapat disimpulkan bahwa secara parsial sektor primer berpengaruh berpengaruh signifikan terhadap NPF.

Berdasarkan hasil uji secara parsial, dapat diketahui bahwa peubah sektor sekunder memiliki sig $>0,05$ yaitu sebesar 0,994 maka $\mathrm{H}_{0}$ diterima, dan dapat disimpulkan bahwa secara parsial sektor sekunder tidak berpengaruh signifikan terhadap NPF.

Berdasarkan hasil uji secara parsial, dapat diketahui bahwa peubah sektor tersier memiliki sig $>0,05$ yaitu sebesar 0,172 maka $\mathrm{H}_{0}$ diterima, dan dapat disimpulkan bahwa secara parsial sektor tersier tidak berpengaruh signifikan terhadap NPF.

\section{Tabel 11.}

Hasil Uji T Coefficients ${ }^{a}$

\begin{tabular}{|c|c|c|c|c|}
\hline & \multicolumn{2}{|c|}{$\begin{array}{c}\text { Unstandardized } \\
\text { Coefficients }\end{array}$} & \multirow[t]{2}{*}{$\mathrm{T}$} & \multirow[t]{2}{*}{ Sig. } \\
\hline & B & Std. Error & & \\
\hline \multirow{6}{*}{$\begin{array}{l}\text { (Constant) } \\
\text { Pembiayaa } \\
\text { n Sektor } \\
\text { Primer } \\
\text { Pembiayaa } \\
\text { n Sektor } \\
\text { Sekunder } \\
\text { Pembiayaa } \\
\text { n Sektor } \\
\text { Tersier }\end{array}$} & .410 & .020 & 20.4 & .000 \\
\hline & & & & \\
\hline & .885 & .267 & & .002 \\
\hline & .002 & .329 & .007 & .994 \\
\hline & & & & \\
\hline & -.799 & .578 & $\begin{array}{r}1.38 \\
3\end{array}$ & .172 \\
\hline
\end{tabular}

\section{PEMBAHASAN}

Dari hasil regresi analisis data secara statistik dalam penelitian ini menunjukkan bahwa secara simultan pembiayaan sektor ekonomi primer, pembiayaan sektor ekonomi sekunder, dan pembiayaan sektor ekonomi tersier memiliki pengaruh signifikan terhadap NPF Perbankan Syariah di Indonesia. Hal ini dibuktikan dengan nilai yang lebih kecil dari alfa 5\% (sig $0.001<a$ $0.05)$.

Apabila secara parsial, pembiayaan sektor primer berpengaruh signifikan 
Mufidah, et al/Jurnal Ekonomi Syariah Teori dan Terapan Vol. 3 No. 5 Mei 2016: 402-417; PENGARUH PEMBIAYAAN SEKTOR EKONOMI PRIMER, SEKTOR EKONOMI SEKUNDER, DAN SEKTOR EKONOMI TERSIER TERHADAP NON PERFORMING FINANCING (NPF) PADA PERBANKAN SYARIAH DI INDONESIA PERIODE 2010-2015 (MARET)

terhadap NPF. Hal ini dibuktikan dengan signifikansi sebesar 0,002 dimana nilai signifikansinya lebih kecil dari 0.05 . Selanjutnya jika dilihat dari nilai positif pada koefisien pembiayaan sektor primer memiliki arti bahwa pertumbuhan pembiayaan sektor primer searah dengan pertumbuhan NPF.

Sektor ekonomi primer terdiri atas sektor ekonomi pertanian; kehutanan; dan sarana pertanian dan sektor ekonomi pertambangan. Sektor primer merupakan sektor ekonomi yang memanfaatkan sumber daya alam secara langsung. Pemanfaatan sumber daya alam secara penuh dan efisien menjadi sasaran yang tak terpisahkan dari sistem Islam. Menurut Islam semua sumber daya di bumi dan langit diperuntukan bagi kesejahteraan manusia dan perlu di eksploitasi secara memadai dan bertanggung jawab pandangan tersebut terurai pada Al-Qur'an Surat Albaqarah ayat 29:

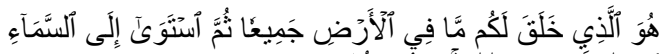

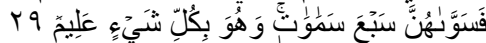
Dialah Allah, yang menjadikan segala yang ada di bumi untuk kamu dan Dia berkehendak menuju langit, lalu dijadikan-Nya tujuh langit. Dan Dia Maha mengetahui segala sesuatu (Departemen Agama, 2010:10).

Ayat ini menjelaskan peringatan

Allah yaitu Allah telah menganugerahkan karunia yang besar kepada manusia, menciptakan langit, dan bumi untuk manusia dan diambil manfaatnya sehingga manusia dapat menjaga kelangsungan hidupnya dan agar manusia berbakti terhadap Allah (Rivai dan Buchari, 2013:27).

Sektor ekonomi primer ini sangat tergantung pada alam atas ketidakpastian kuantitas dan kualitas yang dihasilkan. Penyaluran pembiayaan pada sektor ini memiliki risiko yang tidak dapat dikendalikan, seperti tanah longsong, banjir, kekeringan dan bencana alam lainnya yang tidak dapat dihindari dalam mejalankan usaha pada sektor ini. Adanya risiko ini sangat potensial menimbulkan pembiayaan bermasalah pada sektor ekonomi primer tersebut.

Sedangkan pada sektor sekunder, hasil regresi analisis data dalam penelitian ini, variabel pembiayaan sektor sekunder memiliki hubungan positif terhadap NPF. Hal ini dapat kita lihat bahwa variabel pembiayaan sektor sekunder memberikan hubungan positif sebesar 0,002 yang artinya ketika pembiayaan sektor sekunder naik sebesar 1\% maka akan berdampak pada pertumbuhan NPF sebesar 0,002.

Secara parsial, dengan menggunakan uji t-statistik menunjukkan bahwa variabel pembiayaan sektor sekunder tidak berpengaruh signifikan terhadap NPF. Hal ini dibuktikan dengan nilai signifikansi lebih besar dari alfa 5\% (sig $0,994>$ a 0,05).

Sektor sekunder merupakan sektor yang terdiri atas sektor industri; sektor listrik, gas, dan air; serta sektor konstruksi. Sektor 
Mufidah, et al/Jurnal Ekonomi Syariah Teori dan Terapan Vol. 3 No. 5 Mei 2016: 402-417; PENGARUH PEMBIAYAAN SEKTOR EKONOMI PRIMER, SEKTOR EKONOMI SEKUNDER, DAN SEKTOR EKONOMI TERSIER TERHADAP NON PERFORMING FINANCING (NPF) PADA PERBANKAN SYARIAH DI INDONESIA PERIODE 2010-2015 (MARET)

listrik, gas dan air merupakan sektor penunjang seluruh kegiatan ekonomi dan sebagai infrastuktur yang mendorong aktivitas produksi sektoral maupun untuk kebutuhan konsumsi masyarakat. Hampir seluruh industri di Indonesia membutuhkan listrik, gas dan air dalam mendukung kegiatan produksinya sehingga terjadi peningkatan konsumsi terhadap sumber energi tersebut. Dengan melihat kondisi ini, bank syariah melihat peluang besar atas permintaan stabil pada sektor ini. Sehingga perbankan syariah menyalurkan pembiayaannya pada sektor ini dalam periode 2010 sampai 2015 rata-rata sebesar $12,55 \%$ dari total pembiayaan yang disalurkan.

Hasil penelitian ini sesuai dengan hasil penelitian yang dilakukan oleh Basori (2009) yang menunjukkan bahwa secara parsial sektor sekunder tidak berpengaruh secara signifikan terhadap NPF. Pada sektor sekunder yang terdiri dari sektor-sekor perindustrian, listrik, gas, air, dan konstruksi memiliki keuntungan yang konstan karena produk-produk yang dihasilkan merupakan kebutuhan sehari-hari sehingga permintaannya cukup stabil dan sebagian besar perusahaan yang didanai berbentuk BUMN dan bersifat monopoli dalam menguasai hajat hidup orang banyak serta campur tangan pemerintah juga menjamin pada sektor sekunder ini.
Secara parsial sektor ekonomi tersier tidak berpengaruh signifikan terhadap NPF. Hal ini dibuktikan dengan signifikansi sebesar 0,172 dimana nilai signifikansinya lebih besar dari 0,05 . Selain itu, dari hasil regresi anilisis data penelitian ini, variabel pembiayaan sektor tersier memiliki hubungan negatif terhadap NPF. Hal ini dapat dilihat bahwa variabel pembiayaan sektor tersier memberikan hubungan negatif sebesar 0,799 . Artinya, ketika pembiayaan sektor tersier naik sebesar $1 \%$ maka akan berdampak pada penurunan NPF sebesar 0,799 .

Sektor ekonomi tersier ini terdiri atas sektor perdagangan, restoran dan hotel; sektor pengangkutan, pergudangan, dan komunikasi; sektor jasa dunia usaha; sektor jasa sosial atau masyarakat; dan sektor lain. Pada sektor ini adalah sektor yang menguntungkan bagi perbankan syariah. Berdasarkan penelitian ini, menunjukkan semakin tinggi pembiayaan yang disalurkan pada sektor ini, menyebabkan nilai NPF semakin menurun.

Perbankan syariah memberikan porsi pembiayaan yang besar pada sektor tersier daripada sektor primer dan sekunder. Bank syariah menyalurkan 83,18\% pada sektor tersier dari total pembiayaan yang disalurkan. Hal ini menunjukkan bahwa perbankan syariah mendapat kepercayaan masyarakat dalam mendanai kebutuhan pembiayaan jasa sosial yang meliputi jasa 
Mufidah, et al/Jurnal Ekonomi Syariah Teori dan Terapan Vol. 3 No. 5 Mei 2016: 402-417; PENGARUH PEMBIAYAAN SEKTOR EKONOMI PRIMER, SEKTOR EKONOMI SEKUNDER, DAN SEKTOR EKONOMI TERSIER TERHADAP NON PERFORMING FINANCING (NPF) PADA PERBANKAN SYARIAH DI INDONESIA PERIODE 2010-2015 (MARET)

sosial masyarakat, pendidikan, kesehatan. Sektor ini juga didukung sektor pada bidang perdagangan, restoran dan hotel serta sektor pengangkutan, pergudangan dan komunikasi menjadi sektor pasar yang memberi keuntungan besar bagi bank syariah. Salah satu yang mendorong meningkatnya pembiayaan ini adalah adanya pasar bebas yang mengharuskan Indonesia meningkatkan fasilitas dibidang ini khususnya sektor perdagangan, pengangkutan dan komunikasi untuk menunjang masyarakat dapat bersaing dengan negara-negara lain.

Hasil penelitian ini sesuai dengan hasil penelitian yang dilakukan oleh Basori (2009) dan Taufiqurrochman (2008) menunjukkan bahwa secara parsial pembiayaan sektor tersier tidak berpengaruh terhadap NPF. Selama periode penelitian tersebut terjadi krisis global yang berpengaruh terhadap turunnya pasar modal, akan tetapi pasar modal syariah masih menguntungkan walaupun pertumbuhannya melambat. Sehingga bank syariah tetap mempercayakan pembiayaan pada sektor ini. Selain itu, banuak sektor UMKM yang bergerak pada bidang perdagangan dan jasa tetap menunjukkan prospek yang menguntungkan dan tetap menjadi favorit bank syariah.

Pernyatan ini juga didukung oleh penelitian yang dilakukan oleh Kholistiyah
(2010) menyatakan bahwa pembiayaan sektor pengangkutan, jasa dunia usaha, dan lain-lain terhadap pengaruh positif dan signifikan terhadap laba bank syariah yang disebabkan karena sektor ini memiliki tingkat penyerapan pasar cukup tinggi dan memiliki keuntungan yang tinggi.

Sehingga dari ketiga sektor, sektor tersier ini merupakan sektor yang paling baik bagi bank untuk menyalurkan dananya. Selain memberikan tingkat keuntungan yang tinggi, pertumbuhan pembiayaan pada sektor ini juga berpengaruh negatif terhadap NPF.

\section{SIMPULAN}

Simpulan yang dapat diambil dari hasil penelitian yang sudah dilakukan dengan menggunakan uji statistik adalah sebagai berikut:

1. Secara simultan menunjukkan bahwa pembiayaan sektor ekonomi primer, sektor sekunder, dan sektor tersier berpengaruh signifikan terhadap NPF dengan tingkat sig 0,001 pada taraf nyata 0,05 .

2. Seacara parsial pembiayaan sektor ekonomi primer berpengaruh signifikan terhadap NPF dengan nilai $\beta$ sebesar 0,002 . Sedangkan pembiayaan sektor ekonomi sekunder tidak mempunyai pengaruh yang signifikan terhadap NPF dengan nilai $\beta$ sebesar 0,994, dan pembiayaan sektor ekonomi tersier tidak mempunyai pengaruh yang signifikan 
Mufidah, et al/Jurnal Ekonomi Syariah Teori dan Terapan Vol. 3 No. 5 Mei 2016: 402-417; PENGARUH PEMBIAYAAN SEKTOR EKONOMI PRIMER, SEKTOR EKONOMI SEKUNDER, DAN SEKTOR EKONOMI TERSIER TERHADAP NON PERFORMING FINANCING (NPF) PADA PERBANKAN SYARIAH DI INDONESIA PERIODE 2010-2015 (MARET)

terhadap NPF dengan nilai $\beta$ sebesar -

0,799 .

Saran yang diajukan berdasarkan hasil penelitian yang sudah diperoleh adalah sebagai berikut:

1. Untuk Perbankan Syariah

a. Bank syariah perlu lebih memprioritaskan penyaluran pembiayaan pada pengembangan sektor tersier karena hasil penelitian menyebutkan bahwa sektor ini memiliki hubungan negatif terhadap NPF dan memiliki pasar yang potensial untuk mendapatkan laba yang tinggi.

b. Pada sektor ekonomi primer dan sekunder yang menunjukkan hubungan positif terhadap NPF, diharapkan perbankan syariah dapat meningkatkan prinsip kehati-hatian untuk mengurangi faktor penyebab terjadinya pembiayaan bermasalah dan meningkatkan kapabilitas manajemen pembiayaan bermasalah yang efektif untuk mengurangi pembiayaan bermasalah, mendeteksi dan memproteksi lebih dini terhadap pembiayaan non lancar serta memiliki struktur alokasi pembiayaan yang efektif dan efisien dan melakukan monitoring secara rutin terhadap para nasabah, agar mempersempit celah dari penyimpangan penggunaan pembiayaan.

\section{Bagi Pemerintah}

1. Diharapkan dukungan lebih dari pemerintah untuk mendukung sektor-sektor yang memiliki tingkat risiko tinggi. Pada sektor ekonomi primer khususnya.

2. Saran bagi pemerintah untuk menanggulangi risiko yang terjadi pada kedua sektor sekunder ini yaitu, pelatihan skill bagi UMKM untuk dapat bersaing didunia bisnis, peningkatan fasilitas dalam negeri sehingga dapat menarik wisatawan baik lokal maupun internasional untuk berkunjung pada daerah-daerah wisata dengan tujuan meningkatkan profit sektor perdagangan, perhotelan, dan komunikasi. Pada sektor industri, diharapkan peran pemerintah untuk mendukung industri skala kecil maupun skala besar untuk dapat mengenalkan produk dalam negeri kedunia internasional dan menimbangkan peraturan pemerintah tentang ketentuan pajak sektor ini yang terlalu tinggi bagi para pelaku bisnis.

3. Bagi Penelitian Selanjutnya 
Mufidah, et al/Jurnal Ekonomi Syariah Teori dan Terapan Vol. 3 No. 5 Mei 2016: 402-417; PENGARUH PEMBIAYAAN SEKTOR EKONOMI PRIMER, SEKTOR EKONOMI SEKUNDER, DAN SEKTOR EKONOMI TERSIER TERHADAP NON PERFORMING FINANCING (NPF) PADA PERBANKAN SYARIAH DI INDONESIA PERIODE 2010-2015 (MARET)

Penelitian ini dapat dijadikan bahan acuan untuk penelitian selanjutnya, dengan memasukkan variabel-variabel lain diluar variabel ini, agar memperoleh hasil yang lebih bervariatif yang dapat menggambarkan hal-hal yang dapat berpengaruh terhadap Non Performing Financing (NPF) dan dapat memperpanjang periode pengamatan. Selain itu dapat dilakukan dengan menganalisis lebih dalam tentang strategi penanganan pembiayaan bermasalah pada sektor ekonomi.

\section{DAFTAR PUSTAKA}

Anshori, Abdul Ghofur. 2007. Perbankan Syariah di Indonesia. Yogyakarta: Gadjah Mada University Press.

Badan Pusat Statistik. 2014. Berita Resmi Statistik. Dalam http://www.bps.go.id Bank Indonesia. 2015. Laporan Perkembangan Perbankan Syariah.

Dalam http://www.bi.go.id.

Basori, M. Hasan Eko. 2009. "Pengaruh

Pertumbuhan Pembiayaan Sektoral Ekonomi terhadap Pertumbuhan Non Performing Financing (NPF) dan Non Performing Loan (NPL) pada Perbankan Indonesia (Periode 2004:01 - 2009:04". Universitas Airlangga Surabaya.

Dendawijaya, Lukman. 2005. ManajemenPerbankan. Bogor: Ghalia Indonesia
Departemen Agama Republik Indonesia. AlQuran \& Terjemahan Dep. Agama. 2010. Lajnah Pentashih Mushaf Al-Qurean. Bandung: Gema Risalah Press.

Kholistya, Nurul. 2010. "Analisis Pengaruh Pembiayaan Ekonomi Sektoral terhadap Laba Bank Syariah di Indonesia". Universitas Airlangga Surabaya.

Muhamad. 2002. Manajemen Bank Syariah. Yogyakarta : UPP UMP YKPN. Nasih, Mohammad. 2013. The Analisis of Non Performing Financing Determinants on Indonesian Islamic Banking. Ekonomika-Bisnis Vol. 4 No.2. Nasution, lur Adnan Buyuung. 2006. Panduan Bantuan Hukum di Indonesia. Jakarta: YLBHI dan PSHK Indeks.

OJK (Otoritas Jasa Keuangan). 2012. Statistik Perbankan Syariah. 2015. Dalam wWw.ojk.go.id

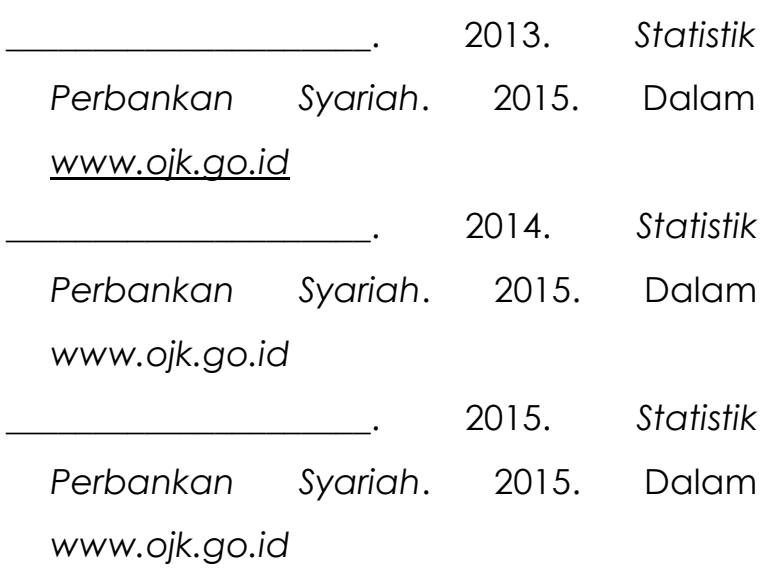

Rivai, Veithzal \& Andi Buchari. 2013. Islamic Economics: Ekonomi Syariah Bukan Opsi, tetapi Solusi. Jakarta: Bumi Aksara. 
Mufidah, et al/Jurnal Ekonomi Syariah Teori dan Terapan Vol. 3 No. 5 Mei 2016: 402-417; PENGARUH PEMBIAYAAN SEKTOR

EKONOMI PRIMER, SEKTOR EKONOMI SEKUNDER, DAN SEKTOR EKONOMI TERSIER TERHADAP NON PERFORMING FINANCING (NPF) PADA PERBANKAN SYARIAH DI INDONESIA PERIODE 2010-2015 (MARET)

Santoso, Singgih. 2000. Latihan SPSS Statistik

Parametrik. Jakarta: PT Elex Media Komputindo

Sujoko, Efferin. 2004. Metode Penelitian Untuk Akuntansi: Suatu Pendekatan Praktis. Malang: Bayu Media Publishing.

Taufiqurrochman. 2008. "Analisis Pengaruh

Pembiayaan Pada Sektor Ekonomi terhadap Tingkat Non Performing Financing (NPF) Perbankan Syariah di Indonesia. Periode Desember 2005 Desember 2007". Universitas Airlangga Surabaya 